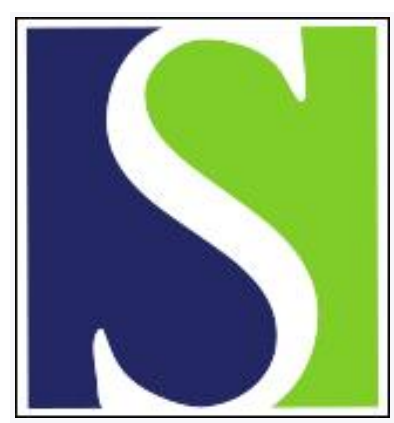

Scand J Work Environ Health 1982;8(3):191-200

https://doi.org/10.5271/sjweh.2476

Issue date: Sep 1982

Evolution of cadmium-induced renal dysfunction in workers removed from exposure.

by Roels H, Djubgang J, Buchet JP, Bernard A, Lauwerys R

This article in PubMed: www.ncbi.nlm.nih.gov/pubmed/7156938

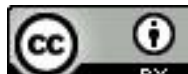




\title{
Evolution of cadmium-induced renal dysfunction in workers removed from exposure
}

\author{
by Harry Roels, PhD, Julienne Djubgang, MD, MIH, Jean-Pierre Buchet, PhD, \\ Alfred Bernard, PhD, Robert Lauwerys, MD, ScD'
}

\begin{abstract}
ROELS H, DJUBGANG J, BUCHET J-P, BERNARD A, LAUWERYS R. Evolution of cadmium-induced renal dysfunction in workers removed from exposure. Scand $j$ work environ health 8 (1982) 191-200. A retrospective examination of the medical records gathered during several surveys carried out among cadmium workers has permitted the identification of a group of 19 workers who had been examined before and after removal from cadmium exposure. All the workers had been exposed for more than 15 a (range 15.6-41.7 a). Their last examination took place from 0.3 to 7.9 a after the date of removal from cadmium exposure. At that time, all the workers exhibited sign(s) of cadmium-induced renal dysfunction. Comparison of the renal function parameters (serum creatinine, total proteinuria, aminoaciduria, albuminuria, $\beta_{2}$-microglobulinuria, and the urinary excretion of retinol-binding protein) before and after the cessation of exposure indicated that cadmium-induced renal lesions, albeit of slow progression, are not reversible when exposure ceases.
\end{abstract}

Key terms: $\beta_{2}$-microglobulinuria, cadmium exposure, irreversible kidney lesions, retinol-binding protein.

Cadmium (Cd) is a naturally occurring element. Every human is exposed to it via food, air, water, and, eventually, via tobacco consumption. Cadmium is produced as a by-product of the refinery of zinc ores. It is used in the fabrication of alloys and solders, in the plating of metals, in pigments and stabilizers in plastic materials, and in alkaline batteries. Its production has increased strikingly since the Second World War.

Cadmium is a cumulative toxic with a biological half-time of more than $10 \mathrm{a}$ in man (14). Chronic exposure to cadmium results in its progressive accumulation in the organism, mainly in the liver and kidneys. In the tissues, cadmium is bound principally to a metal-binding protein of

1 Industrial and Medical Toxicology Unit, School of Medicine, University of Louvain, Brussels, Belgium.

Reprint requests to: $\mathrm{Dr} H$ Roels, Industrial and Medical Toxicology Unit, School of Medicine, University of Louvain, 30.54 Clos Chapelle-aux-Champs, B-1200 Brussels, Belgium. low molecular weight, metallothionein (25).

The kidneys and lungs are the main target organs in cases of excess exposure to cadmium $(19,20,36)$. Lung dysfunction has only been found in workers exposed to cadmium fumes or dust, whereas kidney dysfunction has been detected both in occupationally exposed persons and in the general population $(32,39)$. Usually the kidney is the organ which exhibits the first adverse effects following long-term excess exposure to cadmium by inhalation or ingestion (24).

Friberg (12) first showed that prolonged exposure to cadmium dust causes kidney damage. Since then, this toxic action has been found by many investigators surveying workers exposed to cadmium dust or fumes $(1,2,3,7,9,17,19,23,26,30,34$, $37,38)$.

The classical kidney lesion involves the proximal tubules and a tubular type proteinuria with predominance of low-molecular-weight proteins like $\beta_{2}$-microglobulin, lysozyme, ribonuclease, and retionl-binding protein $(2,8,26)$. It has 
been shown however that cadmium-exposed workers with cadmium-induced renal lesions may not only excrete lowmolecular-weight proteins ( $\beta_{2}$-microglobulin) in larger amounts but also high-molecular-weight proteins like albumin, immunoglobulin-G, and transferrin $(3,7,19)$. These observations suggest that cadmium cannot only affect the reabsorption of lowmolecular-weight proteins by the proximal tubule, but also the mechanisms regulating the excretion of high-molecularweight proteins in the glomerulus and the tubule. In man, the level of cadmium in renal cortex, at which signs of kidney dysfunction occur, has been estimated to be between $215-385 \mu \mathrm{g}$ of cadmium/g of wet weight (33).

The evolution of early renal disturbances after removal from cadmium exposure has not yet been clearly established. Opposite opinions have been formulated. Bonnell et al (8) stated that "when signs or symptoms of poisoning are present, the disease progresses in severity with time and this deterioration occurs in the absence of further exposure to cadmium [p 143]." Adams et al (2) stated that "with cessation of exposure proteinuria has persisted, but there is no evidence that renal function has then continued to deteriorate [p 442]." In a later study Adams (1) stated that "the proteinuria which occurs, is generally progressive once initiated, ever. after exposure to cadmium is subsequently stopped [p 230]." But Tsuchiya (38) presented evidence that proteinuria may be reversible in workers whose exposure to cadmium has ceased or diminished considerably. In a case study conducted by Lauwerys et al (22), of a cadmium worker who had been removed from cadmium exposure because of cadmium-induced renal lesions, no improvement in the intensity of the kidney dysfunction was observed. Piscator \& Petterson (28) hardly observed any change in total proteinuria for several decades after exposure had ceased. Cadmium-induced proteinuria, particularly $\beta_{2}$-microglobulinuria, may also appear after exposure has ceased $(8,28)$. It is, however, not yet known if a very slight proteinuria, as determined by an increased urinary excretion of $\beta_{2}$-microglobulin, may be reversible (27).

In view of the apparently contradictory observations and lack of epidemiologic data on the progressiveness of cadmiuminduced renal damage, we have initiated a study to estimate the outcome of early cadmium-induced renal lesions in workers after they have been removed from cadmium exposure. Two approaches were selected. The first one is a true prospective study of workers who have been removed from cadmium exposure because of signs of renal dysfunction and who are being reexamined once a year for several years. This study is still under way. The second one is based on a retrospective examination of the data collected by our laboratory on cadmium-exposed workers from 1972 to 1980 . The results of this analysis are reported in the present paper.

\section{Subjects and methods}

\section{Study population}

From 1972 to 1980 six cross-sectional surveys were carried out among approximately 200 workers from cadmium-producing plants in Belgium to evaluate the workers' cadmium exposure (cadmium in blood and in urine), and the status of their renal function. These surveys started in May 1972, October 1973, December 1975, April 1976, February 1978, and December 1980; each of them lasted several months.

A retrospective examination of the biological data gathered during these surveys permitted us to identify a group of 19 workers who, by 1980 , had been removed from cadmium exposure and had been examined by us at least once when they were still exposed to cadmium. The following seven biological parameters were considered: cadmium in blood, cadmium in urine, total proteinuria, aminoaciduria, $\beta_{2}$-microglobulinuria, albuminuria, and serum creatinine. Not all of these parameters could be determined for all 19 workers.

Kidney function was considered abnormal when the urinary concentration of $\beta_{2}$-microglobulin exceeded $0.2 \mathrm{mg} / \mathrm{g}$ of creatinine or when urinary albumin exceeded $12 \mathrm{mg} / \mathrm{g}$ of creatinine or when total proteinuria exceeded $250 \mathrm{mg} / \mathrm{g}$ of creatinine $\left(0.2 \mathrm{mg} \quad \beta_{2}\right.$-microglobulin $=0.017$ $\mu \mathrm{mol}, 12 \mathrm{mg}$ albumin $=0.173 \mu \mathrm{mol}, 1 \mathrm{~g}$ creatinine $=8.84 \mathrm{mmol}$ ) 


\section{Collection of samples}

Samples of urine were collected in metalfree polyethylene bottles, and $10 \mathrm{ml}$ was immediately transferred to a tube containing $1 \mathrm{ml}$ of $0.4 \mathrm{~mol} / 1$ phosphate buffer, $\mathrm{pH}$ 7.6. This sample was then stored at $-20^{\circ} \mathrm{C}$ for the subsequent determination of $\beta_{2}$-microglobulin and albumin. Portions of the urine were taken for the determination of creatinine, total proteinuria, and aminoaciduria. Blood was taken by venipuncture for the determination of cadmium and for the separation of serum and the determination of its creatinine level.

\section{Analytical methods}

The same analytical techniques were applied to both the samples collected before and those collected after removal from cadmium exposure. The cadmium concentration in blood and urine was measured by atomic absorption spectrometry as described by Roels et al (31). Creatinine in urine was measured by Jaffe's method (16), and creatinine in serum by the method of Heinegård \& Tiderström (15), slightly modified for automated analysis. The concentration of $\alpha-\mathrm{N}$-amino acids in urine was determined as described by Bernard et al (7). The total protein concentration in urine was measured by the Folin reagent method (19) after the overnight dialysis of urine at $4^{\circ} \mathrm{C}$ against running tap water with the use of $1.8 / 32$ inch Visking dialysis tubing (Medicell International, London) boiled before use for $20 \mathrm{~min}$ in distilled water to avoid the loss of low-molecular-weight proteins. After dialysis, the proteins were precipitated with phosphotungstic acid; bovine serum albumin (Fluka, AG, Buchs, Switzerland) was used as the reference protein. The $\beta_{2}$-microglobulin concentration in urine was measured by radioimmunoassay (11) with the Phadebas $\beta_{2}$-microtest developed by Pharmacia Diagnostics AB (Uppsala, Sweden). The concentration of albumin in urine was determined by nephelometric immunoassay with an automated immunoprecipitation system from the Technicon Instrument Corporation (Tarrytown, NY, United States) (29).

\section{Results}

The characteristics of the population are summarized in table 1. All of the workers had been exposed for more than 15 a to cadmium (range 15.6 to 41.7 a), and their last examination took place from 0.3 to 7.9 a after the date of removal from cadmium exposure.

The mean and range values of each parameter, before and after removal from exposure, are given in table 2. For each parameter, pairs of results (before and after removal) were not available for all 19 workers. The evolution of the individual values is illustrated in fig $1-7$.

\section{Cadmium in blood and urine}

All of the 19 workers had a cadmium blood level that was higher than $1 \mu \mathrm{g} / 100 \mathrm{ml}(8.9 \mathrm{nmol} / 100 \mathrm{ml})$ of whole blood during exposure. The mean cadmium blood level measured on the average 1.2 a before removal was $3.99 \mu \mathrm{g} / 100 \mathrm{ml}$ $(35.5 \mathrm{nmol} / 100 \mathrm{ml})$, and it dropped to 1.41 $\mu \mathrm{g} / 100 \mathrm{ml}(12.5 \mathrm{nmol} / 100 \mathrm{ml}) 4.2$ a (average) after removal. Fig 1 shows the significant decrease in the cadmium level of the blood (paired t-test, $p<0.01$ ) after removal from cadmium exposure, as could be expected since this parameter reflects

Table 1. Characteristics of the workers $(N=19)$ examined before and after removal from cadmium exposure.

\begin{tabular}{|c|c|c|c|c|c|c|}
\hline & \multicolumn{3}{|c|}{ Before removal } & \multicolumn{3}{|c|}{ After removal } \\
\hline & Mean & SD & Range & Mean & SD & Range \\
\hline $\begin{array}{l}\text { Age (a) } \\
\text { Years of cadmium exposure at }\end{array}$ & 54.4 & 5.3 & $40.3-60.6$ & 59.8 & 5.5 & $48.9-67.2$ \\
\hline the time of removal & 27.2 & 8.2 & $15.6-41.7$ & - & - & - \\
\hline Time interval a & 1.2 & 0.9 & $0.1-3.2$ & 4.2 & 2.3 & $0.3-7.9$ \\
\hline
\end{tabular}

a Time interval refers to the number of years between the date of removal and the dates of the examinations before or after removal. 
Table 2. Biological parameters before and after removal from cadmium exposure.

\begin{tabular}{|c|c|c|c|c|c|c|c|}
\hline \multirow{2}{*}{ Parameter a } & \multirow{2}{*}{$\begin{array}{c}\text { Number } \\
\text { of } \\
\text { subjects }\end{array}$} & \multicolumn{3}{|c|}{ Before removal } & \multicolumn{3}{|c|}{ After removal } \\
\hline & & Mean $b$ & SD & Range & Mean b & SD & Range \\
\hline $\begin{array}{l}\text { Cadmium in blood } \\
(\mu \mathrm{g} / 100 \mathrm{ml}) \\
\text { Cadmium in urine }\end{array}$ & 19 & $3.99(3.19)$ & 3.71 & $1.10-17.9$ & $1.41(1.31)$ & 0.56 & $0.57-2.74$ \\
\hline $\begin{array}{l}\text { ( } \mu \mathrm{g} / \mathrm{g} \text { creatinine) } \\
\text { Serum creatinine }\end{array}$ & 19 & $39.4(31.6)$ & 28.1 & $10.8-117.0$ & $16.4(14.7)$ & 9.0 & $8.0-42.3$ \\
\hline $\begin{array}{l}(\mathrm{mg} / 100 \mathrm{ml}) \\
\text { Total proteinuria }\end{array}$ & 11 & 1.23 & 0.31 & $0.89-2.03$ & 1.46 & 0.64 & $1.01-3.29$ \\
\hline $\begin{array}{l}\text { (mg/g creatinine) } \\
\text { Aminoaciduria }\end{array}$ & 19 & 364 (264) & 292 & $44-1,061$ & $325 \quad(236)$ & 289 & $59-1,240$ \\
\hline $\begin{array}{l}\text { (mg } \alpha-\mathrm{N} / \mathrm{g} \text { creatinine) } \\
\text { Albuminuria }\end{array}$ & 18 & 150 & 57 & $89-310$ & 160 & 41 & $93-262$ \\
\hline $\begin{array}{l}\text { (mg/g creatinine) } \\
\beta_{2} \text {-microglobulinuria }\end{array}$ & 14 & $33.2(12.1)$ & 44.6 & $2.3-121.4$ & $34.2(17.0)$ & 10.5 & $3.5-133.3$ \\
\hline (mg/g creatinine) & 11 & $1.70(0.57)$ & 2.35 & $0.03-6.53$ & $11.94(2.82)$ & 25.13 & $0.34-84.65$ \\
\hline
\end{tabular}

a Cadmium: $1 \mu \mathrm{g}=8.9 \mathrm{nmol}$, creatinine: $1 \mathrm{mg}=8.84 \mu \mathrm{mol}, \alpha-\mathrm{N}=1 \mathrm{mg}=0.0714 \mathrm{mmol}$, albumin: $1 \mathrm{mg}=0.0144 \mu \mathrm{mol}, \beta_{2}$-microglobulin : $1 \mathrm{mg}=0.0847 \mu \mathrm{mol}$.

b Geometric mean in parentheses.

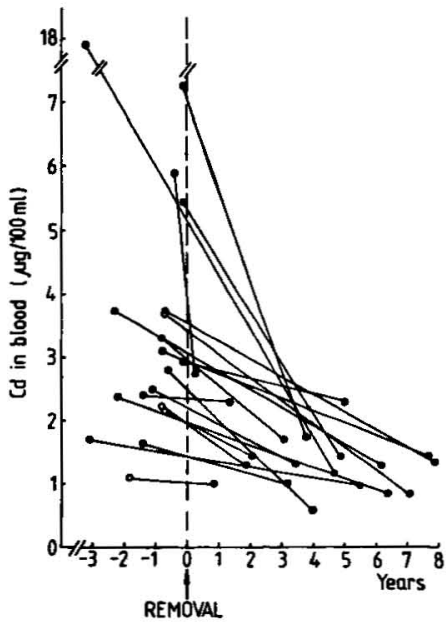

Fig 1. Cadmium (Cd) level in blood before and after removal from cadmium-exposure (open circles: none of the biological parameters of renal function abnormal; closed circles: at least one of the renal biological parameters abnormal). Paired t-test $(N=19): p<0.01$. (Cd :1 $\mu \mathrm{g}=8.9$ nmol)

mainly the last few months of exposure $(18,21)$.

The mean urinary cadmium level measured on the average 1.2 a before removal was $39.4 \mu \mathrm{g} / \mathrm{g}$ of creatinine $(351 \mathrm{nmol} / \mathrm{g}$ creatinine), and it dropped to $16.4 \mu \mathrm{g} / \mathrm{g}$ of creatinine $(146 \mathrm{nmol} / \mathrm{g}$ creatinine) 4.2 a (average) after removal (paired t-test, $\mathrm{p}<0.001$ ) (fig 2). Since all the workers had developed signs of renal disturbance, the decrease in urinary cadmium not only reflects the marked decline in exposure

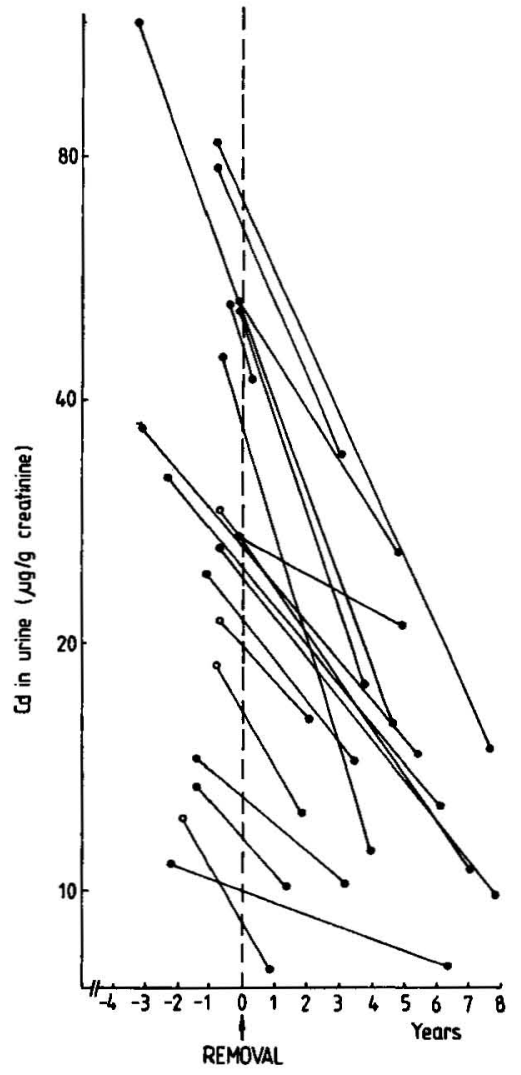

Fig 2. Cadmium (Cd) level in urine before and after removal from cadmium exposure (open circles: none of the biological parameters of renal function abnormal; closed circles: at least one of the renal biological parameters abnormal). Paired t-test $(N=19): p<0.001$. (Cd :1 $\mu \mathrm{g}=$ $8.9 \mathrm{nmol})$ 
intensity, but also the reduction of the cadmium body burden (especially cadmium in kidney), which is accelerated after the occurrence of renal damage $(4,33)$.

\section{Serum creatinine}

Serum creatinine was measured in only 11 workers before and after their removal from cadmium exposure. Their average serum creatinine level, which was 1.23 $\mathrm{mg} / 100 \mathrm{ml}(10.9 \mu \mathrm{mol} / 100 \mathrm{ml})$ [range $0.89-$ $2.03 \mathrm{mg} / 100 \mathrm{ml}(7.9-17.9 \mu \mathrm{mol} / 100 \mathrm{ml})]$ 1.6 a (average) before removal, became $1.46 \mathrm{mg} / 100 \mathrm{ml}(12.9 \mu \mathrm{mol} / 100 \mathrm{ml}$ [range $1.01-3.29 \mathrm{mg} / 100 \mathrm{ml}(8.9-29.1 \mu \mathrm{mol} / 100$ $\mathrm{ml})] 4.1$ a (average) after removal. The paired t-test on the individual values (fig 3) almost reached the level of a statistically significant difference, and it showed a trend towards increasing serum creatinine values after removal from cadmium exposure. This result may indicate a slight exacerbation of the glomerular dysfunction after removal from exposure to cadmium for persons who developed renal dysfunction during their occupational cadmium exposure. It seems unlikely that the observed trend towards increasing serum creatinine after removal from cadmium exposure is related to the increase in age (on the average about 6 a), since serum creatinine does not normally show a significant difference between the age group $50-59$ a and $60-69$ a $(10,35)$.

\section{Total proteinuria}

Total proteinuria was measured for all the workers before and after their removal from cadmium exposure. No significant trend towards a decrease or increase in total proteinuria was detected after removal from cadmium exposure (paired t-test, $\mathrm{p}>0.05$ ) (fig 4).

\section{Aminoaciduria}

About 1.6 a (average) before removal from cadmium exposure, the aminoaciduria levels of 18 workers ranged from $89 \mathrm{mg}$ $(6.4 \mathrm{mmol})$ to $310 \mathrm{mg}(22.1 \mathrm{mmol})$ of $\alpha-\mathrm{N} / \mathrm{g}$

Fig 4. Proteinuria before and after removal from cadmium exposure (open circles: none of the biological parameters of renal function abnormal; closed circles: at least one of the renal biological parameters abnormal). Paired t-test $(N=14): p>0.05$.

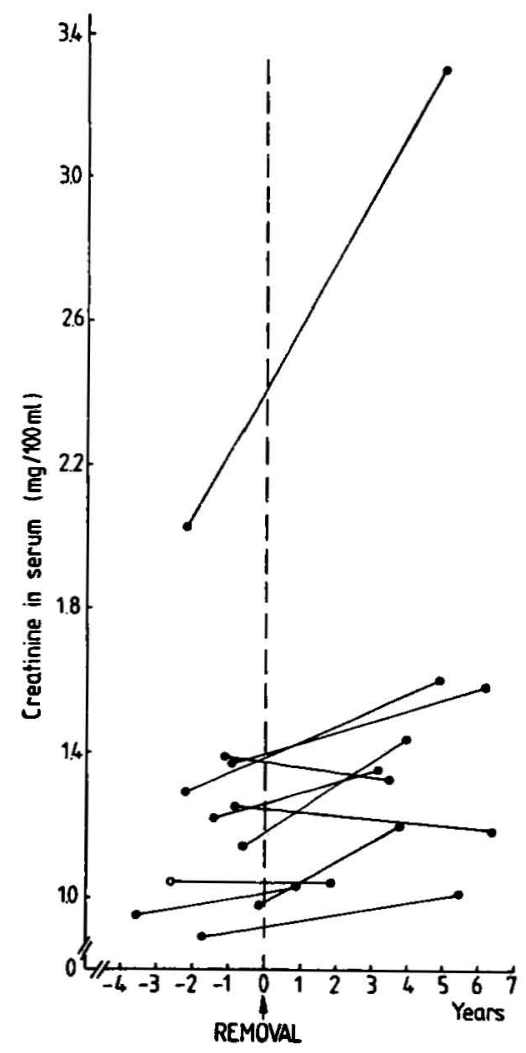

Fig 3. Creatinine in serum before and after removal from cadmium exposure (open circles: none of the biological parameters of renal function abnormal; closed circles: at least one of the renal biological parameters abnormal). Paired t-test $(\mathrm{N}=11): \mathrm{p} \simeq 0.05$. (Creatinine : $1 \mathrm{mg}=$ $8.84 \mu \mathrm{mol}$ )

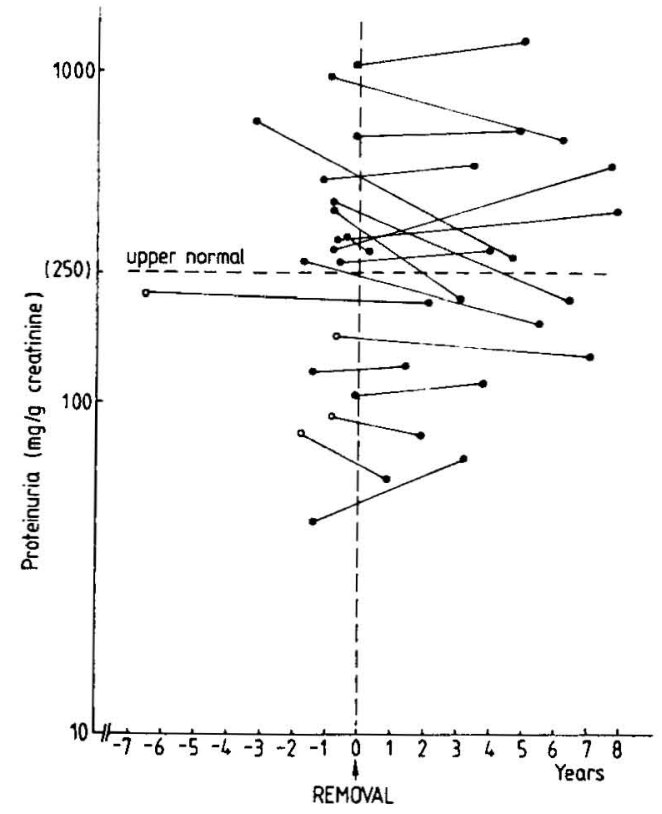




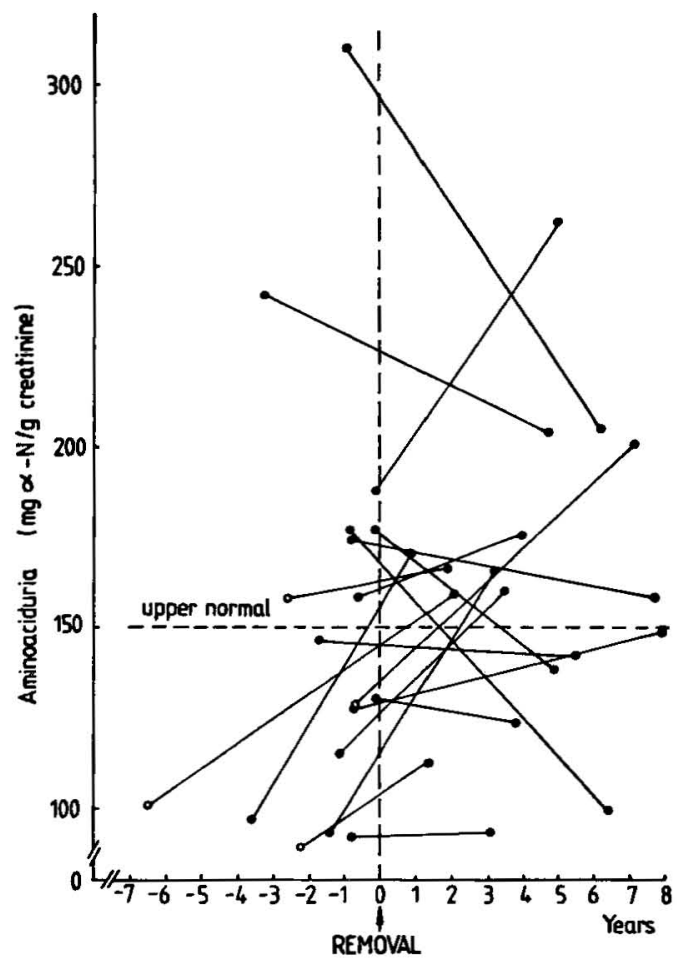

Fig 5. Aminoaciduria before and after removal from cadmium exposure (open circles: none of the biological parameters of renal function abnormal; closed circles: at least one of the renal biological parameters abnormal). Paired t-test $(\mathrm{N}=18): \mathrm{p}>0.05 .(\alpha-\mathrm{N}: 1 \mathrm{mg}=0.0714 \mathrm{mmol})$

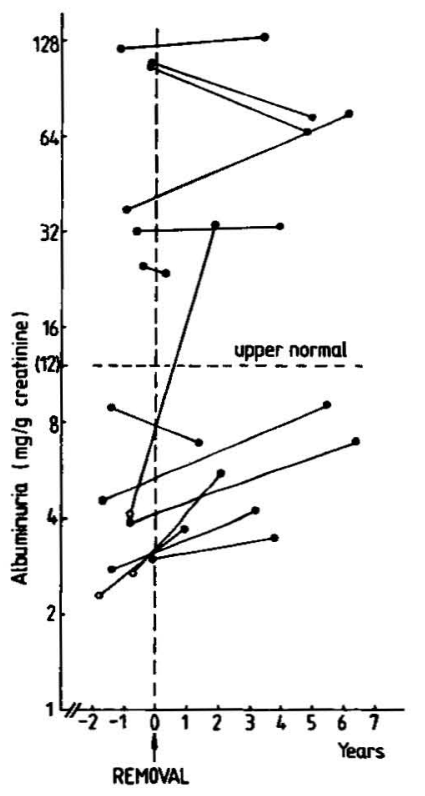

of creatinine with a mean of $150 \mathrm{mg}$ (10.7 mmol) of $\alpha-\mathrm{N} / \mathrm{g}$ of creatinine, and 4.4 a (average) after removal the values ranged from $93 \mathrm{mg}(6.6 \mathrm{mmol})$ to $262 \mathrm{mg}$ (18.7 $\mathrm{mmol})$ of $\alpha-\mathrm{N} / \mathrm{g}$ of creatinine, with a mean of $160 \mathrm{mg}(11.4 \mathrm{mmol})$ of $\alpha-\mathrm{N} / \mathrm{g}$ of creatinine. There was no difference between the values measured in the workers before and after removal from cadmium exposure (fig 5).

\section{Albuminuria}

Albuminuria values were available for 14 workers. The geometric means (table 2) tended to indicate a slight increase in albuminuria after removal from exposure, namely, from $12.1 \mathrm{mg}(0.174 \mu \mathrm{mol})$ to 17.0 $\mathrm{mg}(0.245 \mu \mathrm{mol}) / \mathrm{g}$ of creatinine before and after removal, respectively. The individual values of the 14 workers are presented in fig 6 ; the paired t-test between the values measured before and after removal from cadmium exposure nearly reached the level of statistical significance. These results suggest either a slightly increased permeability of the glomeruli or a decreased reabsorption of albumin by the tubules with time.

\section{$\beta_{2}$-microglobulinuria}

Table 2 presents the mean $\beta_{2}$-microglobulinuria of the 11 workers for whom $\beta_{2}$-microglobulinuria was measured before and after removal from cadmium exposure. The arithmetic mean of $\beta_{2}$-microglobulin in the urine, which was $1.70 \mathrm{mg}$ $(0.144 \mu \mathrm{mol}) / \mathrm{g}$ of creatinine about $0.8 \mathrm{a}$ (average) before removal, was increased by about sevenfold [11.94 mg (1.01 $\mu \mathrm{mol}) / \mathrm{g}$ creatinine] 2.8 a (average) after removal; the geometric mean values were $0.57 \mathrm{mg}(0.048 \mu \mathrm{mol})$ and $2.82 \mathrm{mg}(0.239$ $\mu \mathrm{mol}) / \mathrm{g}$ of creatinine, respectively. Fig 7 illustrates the evolution of $\beta_{2}$-microglobulinuria in these 11 workers, of whom three with normal $\beta_{2}$-microglobulinuria before removal from cadmium exposure developed abnormal $\beta_{2}$-microglobulinuria

Fig 6. Albuminuria before and after removal from cadmium exposure (open circles: none of the biological parameters of renal function abnormal; closed circles: at least one of the renal biological parameters abnormal). Paired t-test $(\mathrm{N}=14)$ : $\mathrm{p} \simeq 0.05$. (Albumin : $1 \mathrm{mg}=0.0144 \mu \mathrm{mol}$ ) 
after they were removed. At the last survey, these 11 workers all had abnormal $\beta_{2}$-microglobulinuria. All the workers exhibited a higher $\beta_{2}$-microglobulinuria level after removal from cadmium exposure in comparison to the level when they were still exposed. This increase was statistically significant (paired t-test: $\mathrm{p}<$ 0.005). It cannot be explained by an age effect since all the subjects were below $70 \mathrm{a}$ of age and no increase in $\beta_{2}$-microglobulin excretion with age has been found in control subjects less than 70 a old (9).

Bernard et al (6) have recently developed a very sensitive latex immunoassay for the analysis of retinol-binding protein in urine. This protein is also excreted in greater amounts in cases of tubular dysfunction (upper normal value $0.14 \mathrm{mg}$ $(0.0065 \mu \mathrm{mol}) / \mathrm{g}$ of creatinine) and has the advantage over $\beta_{2}$-microglobulin of being stable at normal urine $\mathrm{pH}$. Since the urine samples on which $\beta_{2}$-microglobulin was measured had been kept frozen, we have recently reanalyzed them for their retinol-binding protein content. The arithmetic mean of the retinol-binding protein (in $\mathrm{mg} / \mathrm{g}$ of creatinine) was 7.93 $(0.370 \mu \mathrm{mol} / \mathrm{g}$ creatinine $)$ for these 11 workers before removal from cadmium exposure, whereas after removal it had increased to $9.81(0.458 \mu \mathrm{mol} / \mathrm{g}$ creatinine); the geometric means were $0.58 \mathrm{mg}(0.027$ $\mu \mathrm{mol})$ and $1.94 \mathrm{mg}(0.091 \mu \mathrm{mol}) / \mathrm{g}$ of creatinine, respectively. The evolution of retinol-binding protein excretion is therefore in agreement with that of $\beta_{2}$-microglobulinuria.

\section{Discussion and conclusion}

This study was an attempt to evaluate the evolution of cadmium levels in blood and in urine and of cadmium-induced kidney lesions in workers removed from cadmium exposure.

As could be expected, a decrease of the cadmium concentration in blood and urine was observed. This decrease was mainly due to the cessation of the exposure to cadmium and also to the decrease of the cadmium body burden, since it is known that cadmium is lost from the kidney and is excreted in larger amounts in urine when renal dysfunction develops $(18,19$, 20,33 ). It was therefore not relevant in this study to calculate the biological halftime of cadmium in blood and urine after cessation of exposure because of the fact that all the workers showed signs of renal dysfunction and it is known that the onset

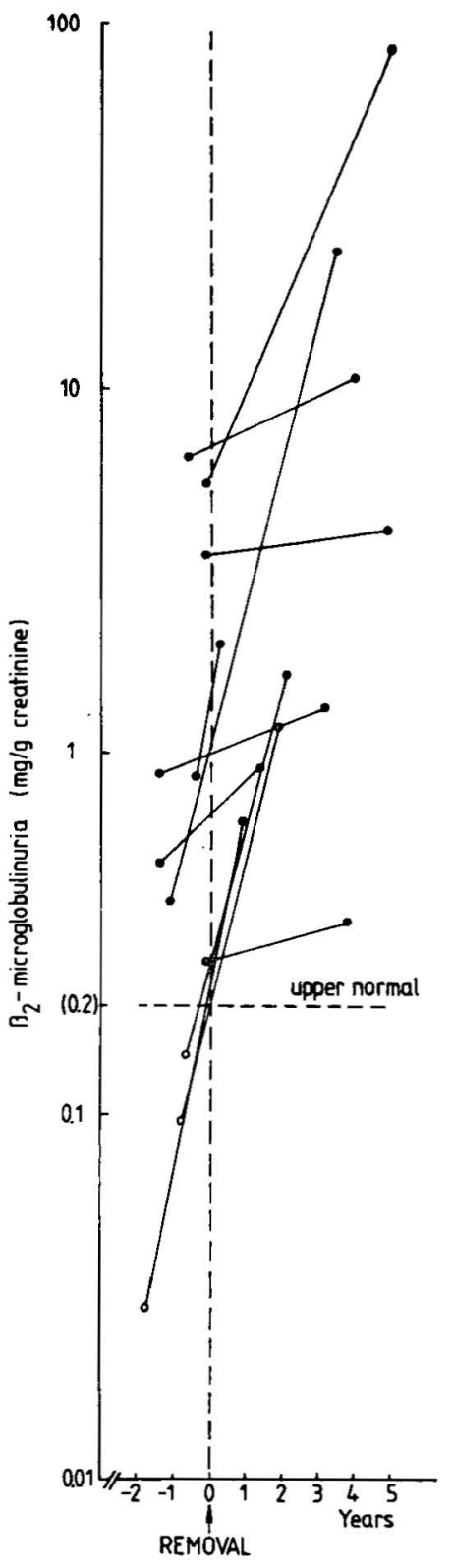

Fig 7. $\beta_{2}$-microglobulinuria before and after removal from cadmium exposure (open circles: none of the biological parameters of renal function abnormal; closed circles: at least one of the renal biological parameters abnormal). Paired t-test $\quad(\mathrm{N}=11): \mathrm{p}<0.005$. $\quad\left(\beta_{2}\right.$-microglobulin : $1 \mathrm{mg}=0.0847 \mu \mathrm{mol})$ 
of renal lesions disturbs the kinetics of cadmium in vivo.

Some parameters, such as serum creatinine and albuminuria, showed a trend towards an increase after removal from cadmium exposure and therefore suggested a slight exacerbation of the glomerular dysfunction. This exacerbation of renal lesions seems to be more evidenced by the evolution of the urinary excretion of $\beta_{2}$-microglobulin and retinol-binding protein, which continued to increase after the cessation of exposure to cadmium. Similarly, Tsuchiya (38) reported suggestive evidence for two cadmium workers with persistent proteinuria, that $\beta_{2}$-microglobulinuria moderately increased after removal from cadmium exposure. This progressive evolution suggests that even at an early stage of cadmium-induced nephropathy, the cessation of exposure does not necessarily prevent the aggravation of the renal tubular lesion. It is interesting to point out that the occurrence of signs of chronic cadmium intoxication after a latent interval following the cessation of exposure to cadmium had also been observed by Friberg \& Nyström (13) and Bonnell et al (8).

No significant increase or decrease in total proteinuria and aminoaciduria was observed in our group of workers after removal from cadmium exposure. However, the fact that their mean values remained above the normal range indicates the persistence of renal dysfunction. This finding is in agreement with the observation of Adams and his co-workers $(1,2)$ that, once proteinuria is established, it persists or progresses even after retirement or change of employment. Studies recently carried out with animals have shown that the nature and the progression of proteinuria induced by cadmium depend on its mode of administration. Whereas the proteinuria induced by the intraperitoneal injection of cadmium is usually of a mixed or tubular type, and is frequently reversible, that induced by a chronic oral administration of cadmium is not reversible and seems to have, in addition to a slight tubular dysfunction, an important glomerular component (5).

The results of the present study suggest that the progressiveness of renal dysfunction after the cessation of exposure is low and probably clinically not significant. However, the persistence of signs of cadmium-induced renal lesions in workers removed from chronic cadmium exposure and even the appearance of these lesions after the cessation of exposure suggest that these renal dysfunctions are not reversible. Furthermore, taking into consideration the fact that our study was not scheduled to follow-up all the subjects removed from cadmium exposure, we do not have to conclude hastily that cadmium-induced renal lesions are always of slow progression after the cessation of exposure. An appropriate follow-up is necessary to estimate better the clinical outcome of cadmium-induced renal disturbances after the cessation of exposure. Such a study is being carried out.

\section{Acknowledgments}

This study was supported by the International Lead Zinc Research Organization.

$\mathrm{Mr} \mathrm{X}$ Dumont, $\mathrm{Mr} \mathrm{T}$ Seminck, and $\mathrm{Mr}$ A Vranckx are gratefully acknowledged for their technical assistance.

\section{References}

1. Adams RG. Clinical and biochemical observations in men with cadmium nephropathy: A twenty-years study. Arch hig rada toksikol (Arch ind hyg toxicol) (Zagreb) (1979): 30 suppl, 219-231.

2. Adams RG, Harrison JF, Scott P. The development of cadmium-induced proteinuria, impaired renal function and osteomalacia in alkaline battery workers. $Q j \mathrm{med}$ 38 (1969) 425-443.

3. Bernard A, Buchet JP, Roels H, Masson PL, Lauwerys R. Renal excretion of proteins and enzymes in workers exposed to cadmium. Eur j clin invest 9 (1979) 11-22.

4. Bernard A, Lauwerys R. The effects of sodium chromate and carbon tetrachloride on the urinary excretion and tissue distribution of cadmium in cadmium-pretreated rats. Toxicol appl pharmacol 57 (1981) $30-38$.

5. Bernard A, Lauwerys R, Gengoux P. Characterization of the proteinuria induced by prolonged oral administration of cadmium in female rats. Toxicology 20 (1981) $345-357$.

6. Bernard A, Moreau D, Lauwerys R. Latex immunoassay of retinol binding protein. Clin chem 28(1982)1167-1171.

7. Bernard A, Roels H, Hubermont G, Buchet JP, Masson P, Lauwerys R. Characterization of the proteinuria in cadmium exposed 
workers. Int arch occup environ health 38 (1976) $19-30$.

8. Bonnell JA, Kazantzis G, King E. A followup study of men exposed to cadmium oxide fume. $\mathrm{Br} \mathrm{j}$ ind med 16 (1959) $135-147$.

9. Buchet JP, Roels H, Bernard A, Lauwerys R. Assessment of renal function of workers exposed to inorganic lead, cadmium or mercury vapor. J occup med 22 (1980) $741-750$.

10. Cockcroft DW, Gault $\mathrm{MH}$. Prediction of creatinine clearance from serum creatinine. Nephron 16 (1976) $31-41$.

11. Evrin PE, Peterson PA, Widell L, Berggård I. Radio-immunoassay of $\beta_{2}$-microglobulin in human biological fluids. Scand $j$ clin lab invest 28 (1971) $439-443$.

12. Friberg L. Proteinuria and kidney injury among workmen exposed to cadmium and nickel dust. J ind hyg toxicol 30 (1948) $32-36$.

13. Friberg L, Nyström A. Läkartidningen 49 (1952) 26-29, quoted by Lauwerys $R$. Cadmium in man: The chemistry, biochemistry and biology of cadmium. Elsevier/North-Holland Biomedical Press, Amsterdam 1979.

14. Friberg L, Piscator M, Nordberg GF, Kjellström $\mathrm{T}$. Cadmium in the environment. Second edition. CRC Press Inc, Cleveland, OH 1974.

15. Heinegård $\mathrm{B}$, Tiderström G. Determination of serum creatinine by a direct colorimetric method. Clin chim acta 43 (1973) 305-310.

16. Henry RJ. Clinical chemistry: Principles and technics. Third edition. Harper and Row, New-York, NY 1965.

17. Lauwerys R, Bernard A, Buchet JP, Roels $H$. Dose-response relationship for the nephrotoxic action of cadmium in man. In: CEP Consultants Ltd. Proceedings of the international conference on management and control of heavy metals in the environment, London Sept 18-23, 1979. Edinburgh 1979, pp 19-23.

18. Lauwerys $R$, Buchet JP, Roels H. The relationship between cadmium exposure or body burden and the concentration of cadmium in blood and in urine in man. Int arch occup environ health 36 (1976) 275285 .

19. Lauwerys $R$, Buchet JP, Roels H, Brouwers J, Stanescu D. Epidemiological survey of workers exposed to cadmium: Effect on lung, kidney and several biological indices. Arch environ health 28 (1974) 145-148.

20. Lauwerys $R$, Roels $H$, Buchet JP, Bernard A, Stanescu D. Investigations on the lung and kidney function in workers exposed to cadmium. Environ health perspect 28 (1979) $137-145$.

21. Lauwerys R, Roels H, Regniers M, Buchet JP, Bernard A, Goret A. Significance of cadmium concentration in blood and in urine in workers exposed to cadmium. Environ res 20 (1979) $375-391$.

22. Lauwerys R, Vos A, Roels $H$, Buchet JP, Bernard A. Surveillance d'un traveilleur écarté de son poste de travail suite à la découverte de lésions rénales induites par le cadmium. Arch belg méd soc hyg méd trav méd lég 37 (1979) 137-146.

23. Materne D, Lauwerys $R$, Buchet JP, Roels $\mathrm{H}$, Brouwers $J$, Stanescu D. Investigations sur les risques de l'exposition au cadmium dans deux entreprises de production et deux entreprises d'utilisation du cadmium. Cah méd trav 12 (1975) 9-76.

24. Nordberg GF. Effects and dose-relationships of toxic metals. Elsevier, Amsterdam 1976 , pp 64-72.

25. Piscator M. On cadmium in normal human kidneys together with a report on the isolation of metallothionein from livers of cadmium exposed rabbits. Nord hyg tidskr 48 (1964) $76-82$.

26. Piscator M. Proteinuria in chronic cadmium poisoning: III Electrophoretic and immunoelectrophoretic studies on urinary proteins from cadmium workers with special reference to the excretion of low molecular weight proteins. Arch environ health 12 (1966) 335-344.

27. Piscator M. Current problems in research on effects of cadmium. In: CEP Consultants Ltd. Proceedings of the international conference on heavy metals in the environment, Amsterdam, Sept 15-18, 1981. Edinburgh 1981, pp 513-517.

28. Piscator M, Pettersson B. Chronic cadmium poisoning: Diagnosis and prevention. In: Clinical chemistry and chemical toxicology of metals. Elsevier/North-Holland Biomedical Press, Amsterdam 1977, pp $143-155$.

29. Ritchie RF, Alper CA, Graves J, Pearson $\mathrm{N}$, Larson C. Automated quantitation of proteins in serum and other biological fluids. Am j clin path 59 (1973) 151-159.

30. Roels H, Buchet JP, Hubermont G, Lauwerys $R$, Masson $P$. Investigations of factors influencing exposure and response to lead, mercury and cadmium in man and animals. Environ health perspect 25 (1978) S1-96.

31. Roels HA, Buchet JP, Lauwerys R, Bruaux $P$, Claeys-Thoreau F, Lafontaine A, Van Overschelde J, Verduyn G. Lead and cadmium absorption among children near a non-ferrous metal plant: A follow-up study of a test case. Environ res 15 (1978) 290308.

32. Roels H, Lauwerys R, Buchet JP, Bernard A. Environmental exposure to cadmium and renal function of aged women in three areas of Belgium. Environ res 24 (1981) $117-130$.

33. Roels HA, Lauwerys R, Buchet JP, Bernard A, Chettle DR, Harvey TC, Al-Haddad IK. In vivo measurement of liver and kidney cadmium in workers exposed to this metal: Its significance with respect to cadmium in blood and in urine. Environ res 26 (1981) $217-240$.

34. Roels HA, Lauwerys R, Materne D, Buchet JP. Study on cadmium proteinuria: Glomerular dysfunction, an early sign of renal impairment? In: Commission of the European Communities. Proceedings of the international symposium on recent ad- 
vances in the assessment of the health effects of environmental pollution, Paris, June 24-28, 1974. Luxembourg 1975, pp $631-641$.

35. Siersbaek-Nielsen K, Mölholm-Hansen J, Kampmann J, Kristensen M. Rapid evaluation of creatinine clearance. Lancet 1 (1971) 1133-1134.

36. Stanescu D, Veriter C, Frans A, Goncette L, Roels H, Lauwerys R, Brasseur L. Effect on lung of chronic occupational exposure to cadmium. Scand j resp dis 58 (1977) $289-303$.
37. Tsuchiya K. Proteinuria of workers exposed to cadmium fume, the relationship to concentration in the working environment. Arch environ health 14 (1967) 875880.

38. Tsuchiya K. Proteinuria of cadmium workers. J occup med 18 (1976) 463-466.

39. Tsuchiya $\mathrm{K}$, ed. Cadmium studies in Japan: A review. Elsevier/North-Holland Biomedical Press, Amsterdam 1978.

Received for publication: 7 July 1982 